\title{
Juridical Analysis of Tax Manipulation Performed by Pontianak City Entrepreneurs as a Corruption Crime in West Kalimantan Province
}

\author{
Gunawan $^{1}$, Faisal Santiago ${ }^{2}$ \\ \{Gunawanigun221@gmail.com¹, faisalsantiago@borobudur.ac.id²\} \\ Universitas Borobudur, Jakarta, Indonesia ${ }^{1,2}$
}

\begin{abstract}
This study aims to answer problems regarding the application of criminal law principles to tax manipulation as a corruption crime in West Kalimantan Province, as well as whether tax manipulation can be qualified as a corruption crime. The research methodology used includes normative and sociological legal research with a literature study and field study approach. The results show that the application of the principles and principles of criminal law to tax manipulation as a criminal act of corruption in West Kalimantan Province is criminal liability, criminal liability is essentially a mechanism built by criminal law to react to violations of the law, and the Tax Manipulation Regulations. so that it meets the requirements. as a Corruption Crime, as for the elements that can be regarded as a criminal act of corruption based on Article 2 paragraph (1) of the Corruption Crime Act, namely "everyone enriches himself, another person or a corporation, by violating the law, and can harm state finances or the state economy". The elements in Article 3 of the Corruption Law are "every person with the aim of benefiting himself or another person, or a corporation, abuses the authority, opportunity or means available to him because of his position or position and can harm state finances. or the country's economy. The conclusion of this research is the description of Article by Article of the KUP Law and the Corruption Crime Act against the cases above, it can be understood that in the case of criminal acts in the field of taxation that are detrimental to state finances, both laws have the authority to resolve criminal acts in the field of taxation. which is detrimental to state finances;
\end{abstract}

Keywords: Crime; Corruption; Tax Manipulation

\section{Introduction}

Indonesia is a welfare state as stated in the Preamble of the 1945 Constitution, 4th paragraph. A prosperous state is the nation's goal in carrying out national development. The success of national development is strongly supported by financing that comes from the community, namely the receipt of tax payments.[1] Taxes are the backbone of Indonesia's state income to achieve the prosperity that the nation aspires to. Taxes come from the 
community and are collected by the government to be collected in order to achieve general welfare.[2]

Tax is a potential source of state revenue in Indonesia. Tax revenue in Indonesia continues to increase every year. Tax is one of the sources of state income that comes from the people. With tax revenues, the government can carry out programs and developments that become public facilities to be enjoyed by all levels of society. However, when viewed from two sides, namely the government and entrepreneurs, they have two different perceptions. If entrepreneurs try to pay taxes to a minimum, then the government tries to get as much tax revenue as possible. According to Saifudin [3], as a profit-oriented company, the company will try to get maximum profit including cost efficiency.

The practice of tax manipulation does not escape systematic tax planning. Tax planning is a business that is used by taxpayers in compiling the company's financial activities so that the tax burden paid by the company is achieved efficiently and effectively. There are two ways to implement tax planning, namely tax evasion and tax avoidance. Tax evasion is an attempt to reduce the payment of the tax burden by violating applicable tax regulations, such as making fake tax invoices. Tax avoidance is defined as an attempt to avoid tax payments made by companies legally and deemed safe by reducing the amount of tax payable and taking advantage of the weaknesses contained in tax regulations without violating them.

Of the two ways, the company's management is more inclined to do tax avoidance because of tax reduction efforts that still comply with tax regulations, so that tax officials can not do anything. Therefore, companies are encouraged to do everything they can to minimize the tax burden. Legally, tax avoidance is not prohibited, but on the other hand it is not expected because state revenues are lower than they should be.

The role of the community in realizing the welfare of the Indonesian people through taxes, one of which is the fulfillment of taxes by multinational companies as taxpayers. Multinational companies that are taxpayers who interact between companies located in Indonesia and those located abroad will be involved with international double taxation, because they are involved in the legal system of a different country. In Indonesia, transfer pricing has been regulated in Permenkeu (Minister of Finance Regulation) No. 22/PMK.03/2020 concerning Procedures for Implementing an Advanced Pricing Agreement. With the existence of these rules, then when examined from the legal aspect of transfer pricing is a legal matter. The practice of transfer pricing will also have an impact on the tax payments of a multinational company, namely in accordance with Law no. 36 of 2008 concerning Income Tax. However, in practice multinational companies often relocate their income to countries with low tax provisions (low tax countries) and transfer larger amounts of costs to countries with high tax provisions (high tax countries). This means that there is a transfer of tax obligations from countries that have high tax rate provisions to countries that apply low tax provisions.

In the midst of uncertainty, a quick policy response from the Government is very important. In the field of taxation, the Government has adjusted the tax revenue target twice, first with the issuance of Presidential Regulation (Perpres) Number 54/2020 on April 3, 2020, which revised the tax revenue target to $\mathrm{Rp} 1,254.11$ trillion. The amount of this target was revised again through Presidential Decree No. 72/2020 on June 24, 2020, by adjusting the tax revenue target to Rp1,198.82 trillion. This adjustment not only takes into account the pressures on the economy that have resulted in a shrinking tax base, but also reflects the role that the tax administration will play in contributing to maintaining Indonesia's economic stability and guarding the National Economic Recovery, particularly in the form of providing tax incentives. 
The incentives provided are in the form of Article $21 \mathrm{PPh}$ borne by the Government, exemption from Article 22 Import $\mathrm{PPh}$, exemption from Import VAT for the needs of the Covid-19 pandemic, reduction in corporate income tax rates, reduction in Article $25 \mathrm{PPh}$ installments, Final PPh borne by the Government for MSME Taxpayers, as well as restitution facilities. accelerated to maintain taxpayer liquidity.

In practice, there are differences in interests in the company, both shareholders who act as principals and management who act as agents in responding to tax avoidance. From the perspective of shareholders, they expect the financial statements to be submitted in accordance with the conditions that occur or at least approach the actual condition of the company, both tax reports and reports for investors. However, management actually prepares financial statements in such a way as to avoid paying too much tax. In this case, the management (agent) morally feels they have a responsibility to maximize the profits of the shareholders (principal), so management gets compensation according to the agreed contract in return. However, management often abuses the interests of shareholders for personal welfare. The reason the shareholders (principals) forbid management (agents) from avoiding tax is because it can affect the company's image which may be bad. If the management makes a wrong decision, the risks that occur will also be fully borne by the owners and shareholders.

\section{Methods}

Research is a scientific way to get data with certain goals and uses.[4] The purpose of this research should be stated clearly and concisely to give direction to the research.[5] The function of a study is to find out a problem to be studied, both social sciences, legal sciences, and other sciences. This study uses a normative juridical approach.

\section{Discussion}

Transfer pricing arises as a result of trade traffic or mobility across country jurisdictions: Assets or goods or tangible property, Assets or goods or intangible property (hereinafter referred to as intangibles), Services, or Capital. Transfer pricing on the things that have been mentioned have value or benefits that arise, which can then be enjoyed by the transacting party. The parties to the transaction prefer to report higher profits in a country jurisdiction with lower tax rate provisions or where they can use the excuse of fiscal loss compensation.

Transfer pricing manipulation also occurs in multinational companies with corporate affiliates in Indonesia. The Asian Agri Group (AAG) company with several affiliated companies that have caused losses in Indonesia of one trillion two hundred fifty-nine billion nine hundred seventy-seven million six hundred ninety-five thousand six hundred and fiftytwo rupiah. Engineering sales of AAG's products overseas with the aim of changing the selling price that should have been to the End Buyer to a lower price (under invoicing) to these companies in Hong Kong so that the profit (profit) obtained by companies in Indonesia will be lower. All sales invoices for companies that have joined AAG as well as companies in Hong Kong, Macau and BVI are carried out in Medan by AAG employees. As a result of the export sales transaction by way of under-invoicing that has been carried out, the reported profit of companies in Indonesia is lower than it actually is, causing the reported tax payable to be smaller than it actually is. 
Transfer pricing manipulation that has occurred as in the case above can harm the state's opinion from the tax sector, even the losses that can be caused can reach Rp. 1.300 trillion/year or equal to $114 \%$ tax revenue.

Law enforcement in the field of taxation is included in the category of administrative crime. According to Kuswandi, in the context of sanctions in the field of taxation, tax law is "quasi criminal law" or "non-genuin criminal law", or quasi criminal law, namely administrative law sanctions that are strengthened by criminal sanctions. Tax law (administration) in it, administrative sanctions are "primum remidium", and criminal sanctions are "ultimum remidium" against administrative sanctions, in the sense that criminal sanctions are only to strengthen administrative sanctions, if the Taxpayer is uncooperative and has no good intentions since to fulfill obligations in accordance with the KUP Law to pay taxes owed or underpaid taxes. Legal umbrella regarding tax law enforcement, especially transfer pricing manipulation through policies. According to Hoefnagels, crime prevention must be pursued through a policy approach, meaning:

1. There is integration between criminal politics and social politics; and

2. There is integration (integrality) between crime prevention efforts with "penal" and "nonpenal".

The existing penal facilities are assessed by the author as not upholding the ultimum remidium principle of the criminal justice system. Where, according to the author, the currently implemented means are not effective, because the high practice of transfer pricing manipulation continues to harm the state in large numbers in the tax sector. Law enforcement is identical to the legal system, where Lawrence Friedman states that the legal system must contain elements of legal structure, legal substance, and legal culture.

Based on this, the authors provide recommendations in efforts to take action against transfer pricing manipulation by multinational companies by:

\subsection{Regulatory Reform Related to Transfer Pricing Manipulation}

Efforts to enforce the law through its legal substance, namely by reforming the rules related to transfer pricing and potentially being misused into transfer pricing manipulation, such as clarifying the substance contained in Law no. 36 of 2008 concerning Income Tax regarding sanctions for parties who evade taxes (see article 18), especially by manipulating transfer pricing and Minister of Finance Regulation No. 36 of 2008 concerning Income Tax. 22/PMK.03/2020 Regarding the Procedure for Implementing the Transfer Pricing Agreement (Advance Pricing Agreement) must also be updated by creating a special division tasked with supervising the practice of transfer pricing manipulation.

\subsection{Prioritizing Law Enforcement in Non-Penal Means}

Non-penal means, namely through the return of assets without going through a criminal route (asset recovery non-convicted based) through this method, there is a paradigm shift that in personam deprivation (focusing on convicting perpetrators/persons) towards in-rem deprivation (focusing on returning assets/goods). 17 The application method of this non-penal means is through penal mediation.

\subsection{Expanding the Authority of the Tax Court}


The role of the court is still needed as a last resort. This effort is in law enforcement as a legal structure, namely through the expansion of the authority of the tax court. The tax court is a judicial body that has judicial power with respect to taxpayers or tax insurers, and has the duty and authority to examine and decide on tax disputes. The expansion of the tax court's authority by optimizing the imposition of legal subjects and objects that are affected by the domicile principle is not limited to this principle but to the parties involved both at home and abroad. This is intended so that there is no longer a gap for unscrupulous multinational companies to manipulate transfer pricing together with affiliated companies located abroad.

\subsection{Transfer Pricing Manipulation Education}

Law enforcement efforts cannot be separated from the community itself which relies on legal culture. Transfer pricing manipulation is considered legal because there are no regulations that prohibit it. Therefore, it is important to hold counseling that educates the whole community, especially those who are indicated to be doing such manipulation, such as companies, that such actions should not be carried out and can be detrimental to the state.

\section{Conclusion}

Tax revenues are decreasing year by year, one of the reasons is the practice of transfer pricing manipulation. This practice is motivated by multinational companies manipulating transfer prices with the aim of getting taxes in a country that has low taxes, as was done by AAG companies. The current legal regulations in Indonesia are considered incapable of quelling the modus operandi of the transfer pricing manipulation. For this matter, it is important to reform from the regulatory aspect, namely by reforming related regulations to more explicitly regulate transfer pricing manipulation, especially in terms of law enforcement or sanctions. Furthermore, in the practice of law enforcement, namely through optimizing nonpenal facilities through penal mediation and the tax court, its duties and authorities need to be expanded, not limited to the domicile principle, but also taking action against parties involved in the practice of transfer pricing manipulation, providing education to the public. general

public. These reforms are recommended by the author for the common interest and to realize the ideals of the nation through the action of transfer pricing manipulation.

\section{References}

[1] D. Fali Rifan, "Analisis Penerapan Tunneling Incentive Dan Mekanisme Bonus Terhadap Praktik Penghindaran Pajak," Fidusia J. Keuang. Dan Perbank., vol. 2, no. 1, pp. 31-37, 2019, doi: 10.24127/jf.v2i1.360.

[2] M. Amalia, Kuswandi, and P. D. Putri, "Analisis Yuridis Manipulasi Transfer Pricing Sebagai Indonesia," in Prosiding Seminar Nasional Online \& Call For Paper Fakultas Hukum Universitas Suryakancana 2020, 2020, pp. 186-194.

[3] S. Saifudin and S. Putri, "Determinasi Pajak, Mekanisme Bonus, Dan Tunneling Incentive Terhadap Keputusan Transfer Pricing Pada Emiten Bei," Agregat, vol. 2, no. 1, pp. 32-43, 2018, doi: 10.22236/agregat.

[4] Ahmad Zuhdi, "Perkembangan Metodologi Penelitian Hukum," J. Huk. dan Perad., vol. 1, no. 2, pp. 189-206, 2012. 
[5] D. Lee, "Research consultations: Enhancing library research skills," Ref. Libr., vol. 41, no. 85, pp. 169-180, 2004, doi: 10.1300/J120v41n85_13. 